\title{
AMERICAN FOREIGN AND DOMESTIC POLICIES ON SPACE EXPLORATION
}

\begin{abstract}
This article is based on a report that was prepared for the International online conference "New Digital Reality: Science and Education, Law, Security, Economics and Finance" on 6th - 11th July 2020.

The article analyzes the activities of NASA, American commercial companies that are engaged in space projects. The article also describes the US policy in the field of space exploration. The author of the article also examines the activities of other countries in the space industry: Russia (formerly the USSR), EU, Japan, India and China.
\end{abstract}

Key words: Space, USA, NASA, domestic policies, Policies space exploration.

DOI: 10.51180/RPS.2020.15.2.011.

\section{Author}

\section{Lamash Maxim}

Student of political science at Pepperdine University (Malibu, USA)

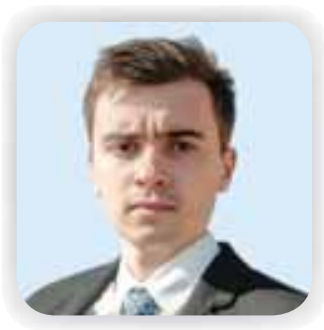

I am here today to speak about the United States foreign and domestic policies toward space exploration and how the importance of new technologies in this field.

Space exploration began in the 1940s and for the first four centuries the only two countries to notably participate in space exploration were the United States and the USSR. During these years of the Cold War, the United States and the USSR were consistently pushing the limits of pace exploration. In 1969 the United States landed the first person on the moon. Two years later, in 1971, the USSR established the first space station. This pattern of aggressive space exploration from both nations continued for the next few decades.

Since 1990, the United States, Russia, Japan, and more recently the European Space Agency have actively participated in Space Exploration. In 2015, in a unified effort between Japan and the United States, the first space grown food was consumed. If anyone is curious, the first space grown food to be consumed was lettuce.

Since 1958 the main agency responsible for the American space program, as well as aeronautics and space research, has been the National Aeronautics and Space Administration, commonly known as NASA. NASA is independent from the U.S. military, operating as an independent agency of the United States Federal government. NASA was explicitly stated to have a "civilian orientation," with the purpose of peaceful space exploration and applications of space science.

NASA has overseen most US space exploration programs since its inception, including Project Gemini, the Apollo Program, the Skylab Program, and the Space Shuttle Program. In 2017 NASA began the Artemis Program which is designed to land "the first woman and the next man" on the moon by 2024. According to NASA, "Artemis would be the first step towards 
the long-term goal of establishing a sustainable presence on the Moon, laying the foundation for private companies to build a lunar economy, and eventually sending humans to mars."

Another component of the United States space program is the inclusion of privately held space exploration companies, including SpaceX lead by entrepreneur Elon Musk. Space $X$ was founded in 2002 and has had numerous successful space missions over the past two decades. NASA has shown a willingness and desire to work with private companies likes SpaceX. An example of this is a recent decision by NASA to hire SpaceX and Boeing to provide transportation to and from the International Space Station instead of building and operating its own aircrafts. Other private companies that participate in the space exploration industry in the United States include Orbital, Northrop Grumman Innovation Systems, and Sierra Nevada Corporation.

While the United States is certainly a leader in Space exploration, it is not the only participant. There is currently greater cooperation amongst nations in space exploration than ever before, in large part due to the International Space Station that was established in 1998. This Station was a collaboration representing an international partnership between the United States, Russia, Canada, Japan, and the participating countries of the European Space Agency. It has been visited by astronauts from 18 countries and is a great example of global cooperation in space exploration.

Additionally, there are other countries that have established space programs. Currently there аге 72 governments that have space agencies. However, of those 72 , only six of the agencies have full launch capabilities. Those agencies are from the United States, Russia, the European Space Agency, Japan, China, and India.

The Russian Federal Space Agency, known as Roscosmos and abbreviated as FKA and RKA, is the Russian equiva- lent of NASA. It was previously the Russian Aviation and Space Agency known as "Rosaviakosmos". The Roscosmos are currently building a new headquarters in Moscow. Recently the Russian Federal Space Agency has been active in its role as a partner in the International Space Station. It is notable that unlike the United States where there are many prominent privately held space exploration companies, the Roscosmos have much more of an exclusive reign over space exploration in Russia. However, it is true that there are a few rising privately held space exploration companies in Russia including Cosmo Course, S7 Space, and Lin Industrial. While the United States and Russia certainly have the most robust space exploration programs, Japan, China, India, and the European Space Agency are all major players as well.

The Japan Aerospace Exploration Agency, known as JAXA, was founded in 2003, although Japan has had a space exploration agency since 1955. In 2018, JAXA and NASA made the following statement to express their commitment to cooperation in the domain of space exploration:

"Consistent with the Japan-U.S. Summit Meeting of November 2017, whereby Prime Minister Shinzo Abe of Japan and President Donald J. Trump of the United States of America noted the long history of bilateral space cooperation between Japan and the United States and affirmed their commitment to continuing cooperation in space exploration between their two nations; Both agencies welcome on coordinating with their governments to enable an innovative and sustainable exploration program."

The United States has taken a similarly cooperative approach with the European Space Agency and the Canadian government. NASA and the Chinese government, however, do not share such a cooperative relationship. Evidence of this rocky relationship is the fact that China banned all researches from NASA from working with 
Chinese citizens affiliated with a Chinese state or entity. Further, in 2011, the United States banned NASA from using its funds to hose Chinese visitors at NASA facilities.

The roots of this contentious relationship between the Chinese and the American space exploration programs are seeded in political turmoil between the two countries. In many ways this is unfortunate that America foreign policy excludes Chinese contribution to the field of space exploration because China undoubtedly has much to offer in terms of resources and innovations. Perhaps in the future political tensions will ease and this will facilitate cooperation between the United States and China. This happened between the United States and Russia following the cold war and has resulted in great collective progress.

Along with the United States, Russia, China, Japan, and the European Space Agency, another country that has a full space exploration program with launch capabilities is India. The Indian Space Research Organization was founded in 1962 and has worked at times with Russia to organize launch programs. Although India is not part of the International Space Station the Indian Space Research Organization does work closely with NASA and the United States. In 2014 Indian and the United States signed the NISAR agreement with a stated mission of a collaborative launch between the two countries by 2022 .

Space exploration is by nature a field with limitless potential. It is difficult for third world countries to justify investing in space exploration if the country does not have the means to provide basic resources for its own citizens. However, for developed countries like the United States, space exploration is an important aspect of the economy. Unlike other countries, the United States does not only have a sophisticated government space exploration agency, but also many privately held firms that contribute to the field of space exploration. For this reason, it is likely that the United States will remain the global leader in space exploration. It is also likely the case that privately held companies in Russia will emerge as major contributors as they have in the United States. In regard to foreign policy, the United States has demonstrated a commitment to working with other countries to achieve the greatest possible results. This is evidenced by their participation in the International Space Station as well as their agreement with India to collaborate on a launch in the near future. The only country with a major space exploration program that the United States does not collaborate with is China, and this is likely a result of political tension between the two countries. Maybe in the future if China and the United States establish a better relationship this will facilitate even greater development of space exploration.

The American policies of utilizing the public and private sector and of working closely with other countries are the reasons why Americans will continue to develop new technologies in the field of space exploration. The field is dependent on innovation, and innovation is dependent on the collaboration of the best minds. By allowing companies like SpaceX to work with NASA, and by working with countries like Russia and India to create and implement new technologies, it can be anticipated that there will be many new technological advances and revolutions in the coming years in the field of space exploration.

Since the United States first starting investing in space exploration it has caught the attention of many. Recently when SpaceX launched the Falcon 9 from Cape Canaveral, people from all over the country and the world eagerly watched. The United States is the global leader in space exploration, and its domestic policy of encouraging private participation as well as government sponsored participation will ensure that its program only continues to grow. Furthermore, the United States foreign policy of cooperating as much as possible with other countries will facilitate even more growth and development in the field. 


\section{References}

1. A New Era for Deep Space Exploration and Development. Product of the White House and National Space Council. 2020. - URL: https://www.whitehouse.gov/wp-content/ uploads/2020/07/A-New-Era-for-Space-Exploration-and-Development-07-23-2020.pdf

2. Alexander Bowe. China's Pursuit of Space Power Status and Implications for the United States. April 11, 2019 - URL: https://www.uscc.gov/sites/default/files/Research/USCC_China's\%20 Space\%20Power\%20Goals.pdf

3. Defense Space Strategy Summary. June 2020. - URL: https://media.defense.gov/2020/ Jun/17/2002317391/-1/-1/1/2020_DEFENSE_SPACE_STRATEGY_SUMMARY.PDF

4. European space policy. Historical perspective, specific aspects and key challenges URL: https://www.europarl.europa.eu/RegData/etudes/IDAN/2017/595917/EPRS_ IDA\%282017\%29595917_EN.pdf

5. Kryshtofor A. P. Determinants of development of international scientific and technical cooperation in the space sphere with the participation of Russia // University Bulletin 2019 - No. 4 - Р. 62-66 [Криштофор А.П. Детерминанты развития международного научно-технического сотрудничества в космической сфере сучастием России // Вестник Университета. — 2019. - №4. - С. 62-66.]

6. Paul Kallender. Japan's New Dual-Use Space Policy. The Long Road to the 21st Century", Asie // Visions. - No. 88. - November 2016. — URL: https://www.ifri.org/sites/default/ files/atoms/files/japan_space_policy_kallender.pdf

7. Rajeswari Rajagopalan, Narayan Prasad. Space India 2.0 - Commerce, Policy, Security and Governance Perspectives // Observer Research Foundation. - 2017. — URL: https://www. researchgate.net/publication/313818553 